\title{
First observation of Posthodiplostomum cuticola (Nordmann, 1832) metacercariae in cypriniformes from Croatia
}

\author{
S. ZRNČIĆ ${ }^{1}$, D. ORAIĆ ${ }^{1}$, Ž. MIHALJEVIĆ ${ }^{1}$, M. ĆALETA ${ }^{2}$, D. ZANELLA ${ }^{2}$, \\ D. JELIĆ 2 M. JELIĆ
}

\begin{abstract}
${ }^{1}$ Croatian Veterinary Institute, Department of Pathology, Savska 143, Zagreb, Croatia, E-mail: zrncic@irb.hr; ${ }^{2}$ Faculty of Sciences, Department of Zoology, Rooseveltov trg 6, Zagreb, Croatia
\end{abstract}

\begin{abstract}
Summary
During an ichthyological study of the Ilova River, rudd (Scardinius erythrophthalmus) infected with Posthodiplostomum cuticola was observed for the first time in Croatia. Later, a more detailed study was made at the same sampling point and the distribution of $P$. cuticola in the fish species present was examined. The condition of the hosts and parasitological indices such as prevalence, mean abundance and mean intensity of all hosts examined were investigated. Metacercariae of $P$. cuticola were most prevalent (100\%) in Rutilus rutilus, Pseudorasbora parva, Leuciscus leuciscus and Alburnus alburnus, slightly lower (93.94\%) in Leuciscus cephalus, substantially lower in Rhodeus amarus (66.67\%) and Barbatula barbatula (50 $\%$ while the lowest prevalence was found in Gobio gobio $(47.83 \%)$. The correlation coefficient between number of parasites and total and standard length, weight and Fulton's condition index of sampled specimen was significant only for L. cephalus.
\end{abstract}

Keywords: Postohodiplostomum cuticola; Digenea; cypriniformes; prevalence; Ilova river

\section{Introduction}

Posthodiplostomum cuticola (Digenea: Diplostomatidae) (Nordmann, 1832) is a digenean trematode parasitizing different fish species, but occurring most frequently in the family Cyprinidae (Schuster et al., 2001; Popiolek \& Kotusz, 2003; Mierzerjewska et al., 2004; Dzika, 2005; Shukerova, 2005). Similarly to other digeneans, P. cuticola has a complicated life-cycle involving three hosts. The snails Planorbis planorbis are the first intermediate hosts (Faltynkova, 2005), various fish species are the second intermediate hosts and piscivorous birds such as herons or bitterns are the definitive hosts (Dönges, 1964).

The metacercariae of $P$. cuticola are present in the skin, fins and musculature of fish and are encysted with melanin forming black cysts, which constitute the main symptom of the disease known as "black spot" (Shukhgalter \& Chukalova, 2002; Ondračkova et al., 2002; Ondračkova et al., 2004a,b).

The parasite is reported as pathogenic. Juvenile fish are more susceptible, showing symptoms such as emaciation, and pathological changes in the musculature, cartilage and also in the kidney, liver and blood (Schaperclaus, 1990; Rolbiecki, 2004).

There are very few references on parasitic diseases of fish from Croatian freshwater in general. The occurrence of freshwater fish parasites has scarcely been studied and thus far published papers mainly deal with the parasitology of farmed fish. During an ichthyological study of the Ilova River in central Croatia, at one of the twelve sampling points, rudd (Scardinius erythrophthalmus) infected by $P$. cuticola was observed for the first time in Croatia. More extensive sampling was performed at the same site to study the proportion of parasite presence. This paper describes the distribution of $P$. cuticola in the population of fish species in the study area, evaluates differences in host body condition and estimates parasitological indices such as prevalence, mean abundance and mean intensity on all examined hosts.

\section{Material and methods}

\section{Study site}

Fish samples were taken from the Ulovćev mlin retention pond on the Ilova River $\left(45^{\circ} 39^{\prime} 40.5^{\prime \prime} \mathrm{N}, 17^{\circ} 13^{\prime} 28.15^{\prime \prime} \mathrm{E}\right)$ (Fig. 1). The retention area is approximately $100 \mathrm{~m}^{2}$ with depth ranging from 10 to $50 \mathrm{~cm}$. A small brook collecting water from an adjacent wetland provides a continuous supply while water from the Ilova River inflows only during high water levels. The water flow is very sluggish and therefore the water temperature is slightly higher than in the river. The bottom is mainly rocky and covered with 
silted gravel with an abundance of aquatic vegetation. An unusually large number of snails was observed on the aquatic plants of the study site.

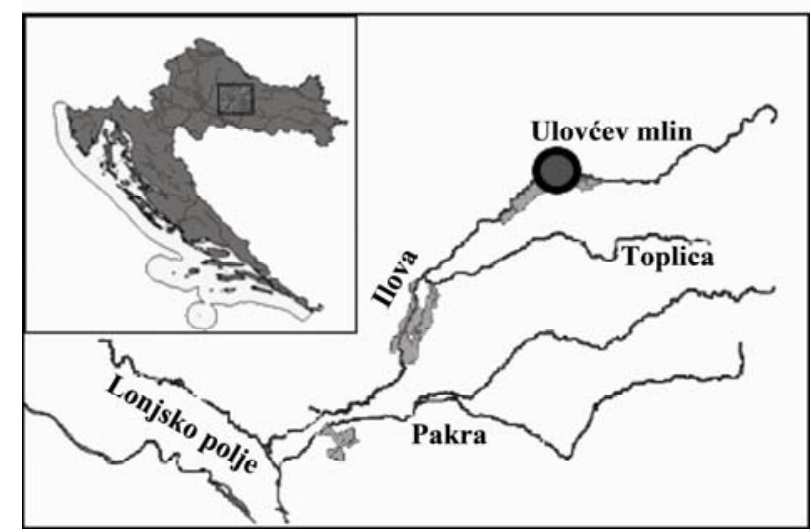

Fig. 1. Retention pond on the Ilova River "Ulovćev mlin" - study site

\section{Fish samples}

Samples of different fish species were obtained by backpack electro fishing and square nets $(1.5 \times 1.5 \mathrm{~m}$ and $2.0 \times 2.0 \mathrm{~m})$. All specimens used in the study were collected during September 2006. Captured fish were preserved in $4 \%$ formaldehyde and later identified using determination keys according to Vuković and Ivanović (1971). Total and standard lengths of each fish from the particular sample were measured in millimetres, mass in grams and the number of cysts was counted.

\section{Parasite infection}

Metarcercariae were prepared for microscopic examination by staining with Semichon's acetocarmine staining technique (Lasee 2001) and identified using keys by Moravec et al. (1991).

For each host species, the level of parasite infection was estimated according to Bush et al. (1997). The prevalence was calculated as follows: percentage of hosts infected by $P$. cuticola; mean abundance as the number of individuals of $P$. cuticola in a sample of particular hosts divided by the total number of hosts; and mean intensity as the average intensity of $P$. cuticola among infected members of a particular host.

The condition factor was determined from the length and weight data of each specimen using Fulton's condition index $\mathrm{KF}=\mathrm{W} \times 100 / \mathrm{TL}^{3}$ (Ricker 1975) where $\mathrm{W}=$ body weight $(\mathrm{g})$ and $\mathrm{TL}=$ total length $(\mathrm{cm})$. The condition factor was then correlated with the parasitological indices.

The relationship between fish length, weight and Fulton's condition index (KF) and the number of P. cuticola was investigated by pairwise correlation analysis and described as Pearson product-moment correlation coefficient (r). Statistical analysis were performed using software package STATA 9 (StataCorp. 2005. Stata Statistical Software: Release 9. College Station, TX: StataCorp LP). The $p<0.05$ was considered significant.

\section{Results}

A total of 90 specimens from three families of the order Cypriniformes were examined. Cyprinidae were represented by chub Leuciscus cephalus, roach Rutilus rutilus, false harlequin Pseudorasbora parva, gudgeon Gobio gobio, bitterling Rhodeus amarus, bleak Alburnus alburnus and dace Leuciscus leuciscus. Balitoridae was represented by stone loach Barbatula barbatula and Cobitidae by the golden loach Sabanejewia balcanica. Condition indices (KF) calculated according to Fulton's equation varied between species and their mean values $( \pm \mathrm{SD})$ for the particular species are shown in Table 1.

Metacercariae of $P$. cuticola present as black cysts were located primarily on the skin, fins, gills and in the subepidermal tissue of all examined species except $S$. balcanica (Table 1). The proportion of infected specimens among those sampled at the study site is presented in Fig. 3. The highest prevalence (100\%) of cysts (Fig. 2) was observed in R. rutilus, P. parva, L. leuciscus and A. albur$n u s$, slightly lower (93.94\%) in L. cephalus, significantly lower in $R$. amarus $(66.67 \%)$ and B. barbatula $(50 \%)$ while the lowest was in G. gobio (47.83\%). Mean intensity was also the highest in $R$. rutilus (63.80), somewhat

Table 1. Total body length, weight, Fulton's condition index (KF) and parasitological infection parameters (prevalence, mean abundance and mean intensity) in fish infected by $P$. cuticola

\begin{tabular}{|c|c|c|c|c|c|c|c|}
\hline Host species & $\mathbf{n}$ & $\begin{array}{c}\text { TL/mm } \\
\text { Mean(SD) }\end{array}$ & $\begin{array}{c}\mathbf{m} / \mathbf{g} \\
\text { Mean(SD) }\end{array}$ & $\begin{array}{c}\text { KF } \\
\text { Mean(SD) }\end{array}$ & $\begin{array}{l}\text { P* } \\
(\%)\end{array}$ & MA** & MI**; \\
\hline Leuciscus cephalus & & 111.36 & 22.74 & 1.69 & & & \\
\hline Chub & 33 & $( \pm 8.79)$ & $( \pm 5.11)$ & $( \pm 0.03)$ & 93.94 & 23.42 & 24.94 \\
\hline $\begin{array}{l}\text { Rutilus rutilus } \\
\text { Roach }\end{array}$ & 5 & $\begin{array}{c}126.6 \\
( \pm 17.17)\end{array}$ & $\begin{array}{c}31.98 \\
( \pm 11.49)\end{array}$ & $\begin{array}{c}1.19 \\
( \pm 0.09)\end{array}$ & 100.0 & 63.8 & 63.8 \\
\hline $\begin{array}{l}\text { Pseudoraspora parva } \\
\text { False Harlequin }\end{array}$ & 11 & $\begin{array}{c}69.73 \\
( \pm 2.19) \\
\end{array}$ & $\begin{array}{c}3.41 \\
( \pm 0.37)\end{array}$ & $\begin{array}{c}0.96 \\
( \pm 0.03)\end{array}$ & 100.0 & 12.46 & 12.45 \\
\hline $\begin{array}{l}\text { Gobio gobio } \\
\text { Gudgeon }\end{array}$ & 23 & $\begin{array}{c}69.61 \\
( \pm 6.55) \\
\end{array}$ & $\begin{array}{c}6.07 \\
( \pm 1.45) \\
\end{array}$ & $\begin{array}{c}0.92 \\
( \pm 0.05) \\
\end{array}$ & 47.83 & 1.17 & 2.45 \\
\hline $\begin{array}{l}\text { Rhodeus amarus } \\
\text { Bitterling }\end{array}$ & 12 & $\begin{array}{c}43.83 \\
( \pm 0.78) \\
\end{array}$ & $\begin{array}{c}0.89 \\
( \pm 0.06) \\
\end{array}$ & $\begin{array}{c}1.95 \\
( \pm 0.08) \\
\end{array}$ & 66.67 & 0.75 & 1.13 \\
\hline
\end{tabular}

Legend: $\mathrm{P}^{*}$ - Prevalence (percentage of infected hosts); MA** - Mean abundance (number of P. cuticola in a sample of particular host divided by the total number of hosts); MI***-Mean intensity (average intensity of $P$. cuticola among infected members of a particular host) 


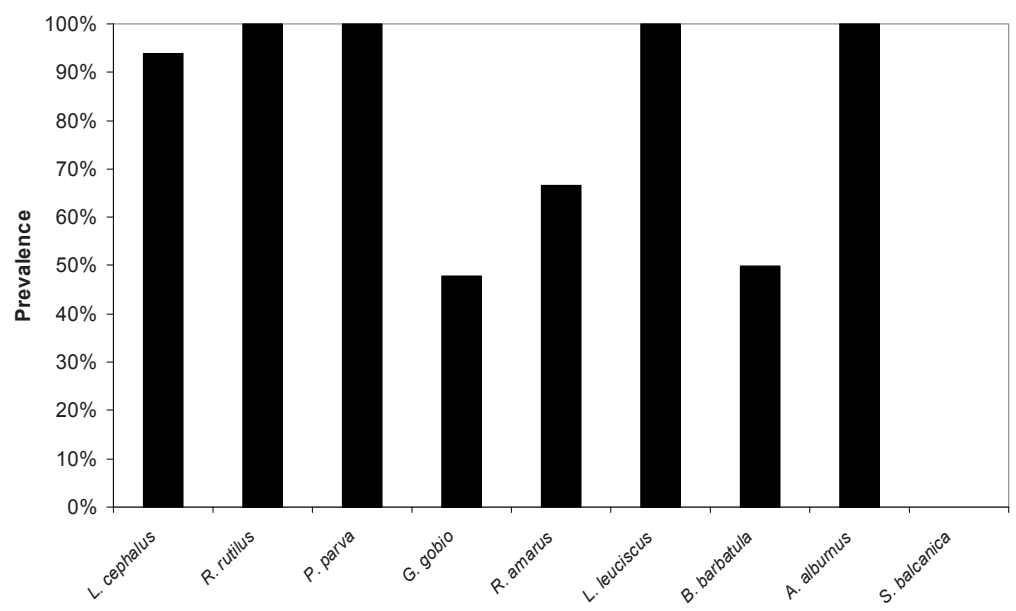

Fig. 2. Prevalence of $P$. cuticola infection in particular fish species

lower in L. cephalus (23.42) and P. parva (12.46) while it was significantly lower in other examined species and ranged from 1.13 in $R$. amarus, 2.0 in B. barbatula and $A$. alburnus, and 2.45 in G. gobio to 3.0 in L. leuciscus. The calculated mean abundance was lowest in $R$. amarus (0.75), slightly higher in B. barbatula (1.0), followed by $G$. gobio (1.17), A. alburnus (2.0), L. leuciscus (3.0), P. parva (12.46), L. cephalus (23.42) while the highest was in $R$. rutilus (63.8).

Correlation analysis between number of parasites and measured fish characteristics (TL, body weight and KF) was performed for species with more than five representatives in the sample (L. cephalus, R. rutilus, P. parva, $R$. amarus and G. gobio). In L. cephalus a significant correlation was found between the number of cysts and TL (r $=0.57, \mathrm{p}=0.0007)$, number of cysts and weight $(\mathrm{r}=0.48$, $\mathrm{p}=0.005)$ and number of cysts and KF $(\mathrm{r}=0.50, \mathrm{p}=$ $0.0031)$ which is visible from Fig. $3 \mathrm{a}, \mathrm{b}$ and c. Correlations between TL, body weight and KF in other sampled fish species like $R$. rutilus, P. parva, R. amarus and G. gobio were not significant $(\mathrm{p}>0.05)$.
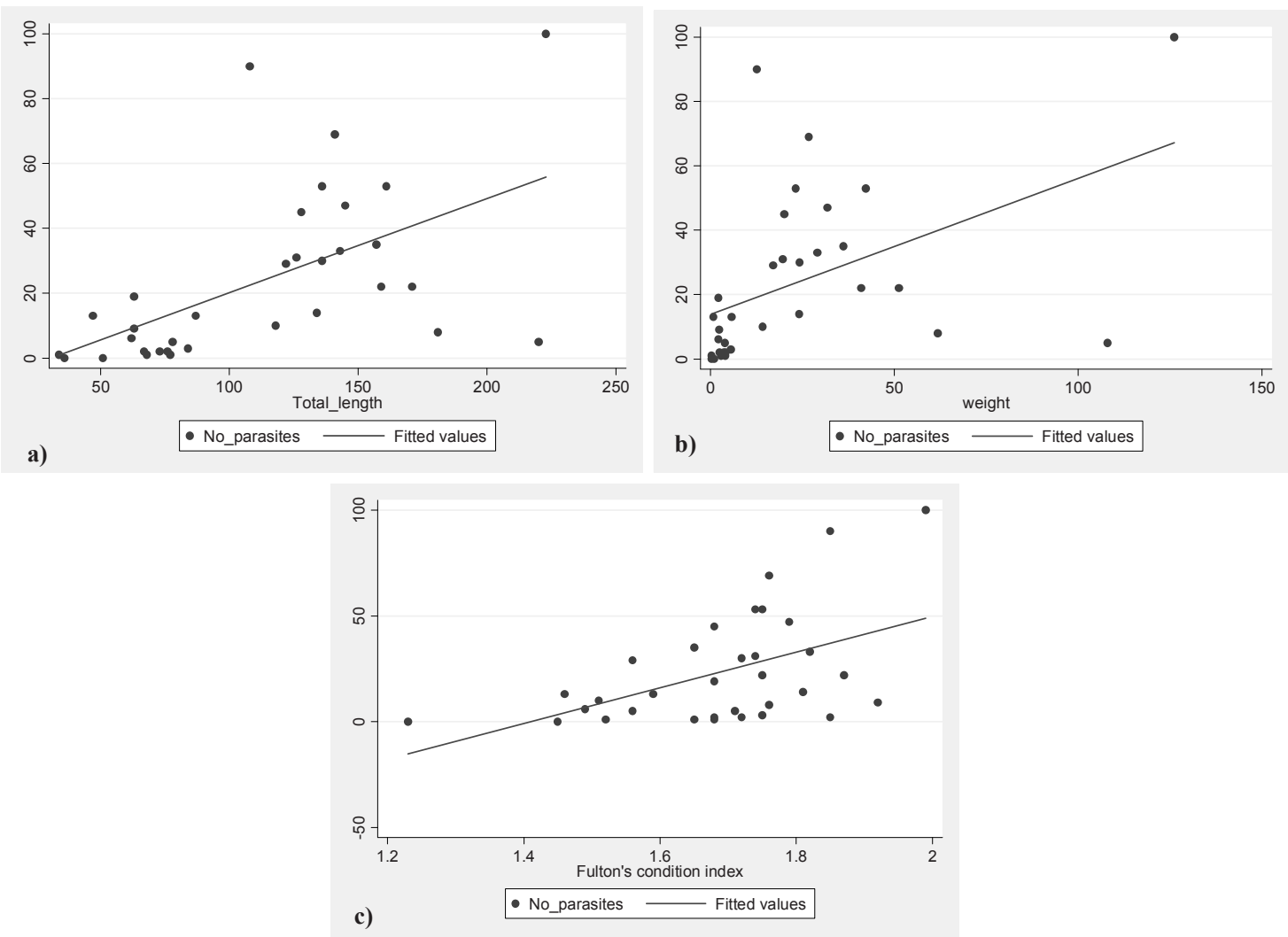

Figure 3. The relationship between (a) TL, (b) weight and (c) KF and number of P. cuticola in Leuciscus cephalus 


\section{Discussion}

Despite periodical parasitological surveys involving different fish species from several Croatian rivers and more regular studies of cultivated fish, $P$. cuticola has not been previously found. The substantially different environmental conditions at the Ulovćev mlin study site (Fig. 1) were convenient for the occurrence of black spot disease. This retention pond is a small water body with occasional water flow, sometimes even flooded, with a higher water temperature than the Ilova River and abundant vegetation inhabited by snails, the first intermediate hosts. Kadlec et al. (2003) suggest that an accumulation of molluscs as intermediate hosts due to flooding could have facilitated the success of the complete life cycle of digeneans. Such water bodies are also likely to attract piscivorous birds as the definitive hosts of $P$. cuticola thereby enabling completion of the life cycle. Contrary to the environmental conditions described here, snails are very rare at fish farms due to zoo technical measures employed in the fish cultivation process (Jokela et al., 1999, 2005). The environmental conditions observed in this study were an important factor for parasite infection and were very similar to those described by Ondračkova et al. (1999) who noticed a high prevalence and abundance of $P$. cuticola infection in fish from flooded borrow pits inhabiting lentic water bodies with dense vegetation. Steedman (1991) concluded that habitat degradation increases the incidence of black spot disease.

During a study of factors contributing to parasite infection and prey selection by definitive bird hosts, Ondračkova et al. $(2004 \mathrm{a}, \mathrm{b})$ revealed that the life-cycle of $P$. cuticola is directly or indirectly influenced by several abiotic factors, in addition to snail density and the community structure of second intermediate hosts (cyprinid and balitorid fish species). In our study, cobitid fishes were represented only by specimens of uninfected $S$. balcanica. This can be explained by the behaviour of this species. They are predominantly benthic species that are not inclined to swimming and therefore, contact with the snail, the first intermediate host, is unlikely. B. barbatula and G. gobio are characterised by similar behaviour but were represented in the sample by a lower number of specimens, and therefore it is difficult to pragmatically evaluate parasite prevalence. Contrary to this fact, most members of the Cyprinidae are good swimmers, with a terminally situated mouth and thus they approach the aquatic vegetation to which snails are attached and cercariae released from them easily infect the cyprinid fish. This is supported by the high prevalence, mean abundance and mean intensity of $P$. cuticola in cyprinid species from the study site (Table 1).

The claim of Ondračkova et al. (2006) that fish infected by $P$. cuticola appear to be easier prey for predators due to the formation of clearly visible black spots seems acceptable, though the second claim that infected fish are better prey because of their poorer condition is not. The results of this study revealed that the Fulton condition index was not poorer in fish with a higher prevalence of $P$. cuticola.

Furthermore, certain studies support the hypothesis that the number of $P$. cuticola is higher in specimen with larger total body length (Mierzejewska et al., 2004) or that hosts' higher value of condition index positively correlate with parasite density value (Neff \& Cargnelli, 2004). These results show that the Fulton's condition index (KF) and the number of parasites significantly correlated $(\mathrm{p}<0.05)$ only for L. cephalus (Fig. 2c), same as other measured parameters analysed in correlation to number of parasites as shown in Fig.2.a and b. Although roach $R$. rutilus had a very high prevalence (100\%), mean intensity (63.8) and mean abundance (63.8) of parasites, the correlation coefficient was not significant $(p>0.05)$ probably due to the insufficient number of infected specimens in the sample.

Considering the available literature data, metacercariae of $P$. cuticola have been described in many freshwater fish species throughout the world. To date, there were no records of black spot disease in Croatia as small and economically unimportant waters are studied very rarely. However, it is possible to conclude that specific environmental conditions foster parasitic infections. Parasite-induced changes in fish behaviour increase susceptibility to predation (Pasternak, 2006), which is obvious under high parasite prevalence. Therefore future parasitological studies of $P$. cuticola should include different aquatic environments to evaluate whether parasitological indices such as prevalence, mean abundance and mean intensity of infected hosts are comparable.

\section{References}

Bush, A. O., Lafferty, K. D., Lotz, J. M., Shostak, A. W. (1997): Parasitology meets ecology on its own terms: Margolis et al. revisited. J. Parasitol., 83: 575 - 583

DönGES, J. (1964): The life cycle of Posthodiplostomum cuticola (v. Nordmann 1832) Dubois 1936 (Trematoda, Diplostomatidae). Z Parasitenkd, 24: 160 - 248

DZIKA, E. (2005): Changes in the parasitic fauna of rudd Scardinius erythrophthalmus (L.) from Lake Warniak, Poland. Helminthologia, 42: $219-222$

FALTYNKova, A. (2005): Larval trematodes (Digenea) in molluscs from small water bodies near Česke Budejovice, Czech Republic. Acta Parasitol., 50: 49 - 55

Jokela, J., Taskinen, J., Mutikainen, P., KoPP, K. (2005): Virulence of parasites in hosts under environmental stress: experiments with anoxia and starvation. Oikos, 108: $156-164$

Jokela, J., Lively, C. M., Taskinen, J., Peters, A. D. (1999): Effect of starvation on parasite-induced mortality in a freshwater snail (Potamopyrgus antipodarum). Oecologia, 119: 320 - 325

Kadlec, D., Šimkova, A., Jarkovsky, J., Gelnar, M. (2003): Parasite communities of freshwater fish under flood conditions. Parasitol. Res., 89: $272-283$

LASEE, B. (2001): General Parasitology. In: U.S. FISH \& 
Wildlife Service. Division of Fish HAtcheries (Eds) Laboratory Procedure Manual. Washington, D.C., USA. MierzerJeWSKA, K., Wlasow, T., KAPUSTA, A., SZYNANCZYK, K. (2004) Fish digeneans from the seven islands ornithological reserve at Oswin lake Poland. Part I. Posthodiplostomum cuticola von Nordmann, 1832. Acta Ichthyol. Piscatoria, 34: $73-84$

Moravec, F., Ergens, R., Našincova, V., Scholz, T. (1991): Parasitic Metazoa. In: SvobodovA, Z., VyKusova, B. (Eds) Diagnostic, prevention and therapy of fish diseases and intoxications. Research Institute of Fish Culture and Hydrobiology, Vodnany, Czechoslovakia. NefF, B. D., CARgnelli, L. M. (2004): Relationship between condition factors, parasite load and paternity in bluegill sunfish, Lepomis macrochirus. Environ. Biol. Fishes, 71: $297-304$

ONDRAČKOVA, M., BARTOSOVA, S., VALOVA, Z., JuRAJdA, P., GELNAR, M. (2004a): Occurrence of black-spot disease caused by metacercariae of Posthodiplostomum cuticola among juvenile fishes in water bodies in the Morava River basin. Acta Parasitol., 49: 222 - 227

OndraČKOVA, M., DAVIDOVA, M., GElnAR, M., JURAJDA, P. (2006) Susceptibility of Prussian carp infected by metacercariae of Posthodiplostomum cuticola (v. Nordmann, 1832) to fish predation. Ecol. Res. 21: $526-$ 529

ONDRAČKOVA, M., DYKOVA, I., JURAJDA, P. (1999): Posthodiplosomatosis of cyprinidae. Helminthologia 36: 125

OndraČKOVA, M., JURAJdA, P., GElnar, M. (2002): The distribution of Posthodiplostomum cuticola metacercariae in young-of-the-year cyprinid fish. J. Fish. Biol., 60: 1355 $-1357$

OndraČKova, M., REICHARd, M., JURAJdA, P., GELnAR, M. (2004b): Seasonal dynamics of Posthodiplostomum cuticola (Digenea, Diplostomatidae) metacercariae and parasite-enhanced growth of juvenile fish. Parasitol. Res., 93: $131-136$

PASTERNAK, M. (2006): Defense behaviour of fish against preators and parasites. J. Ichthyol., 46 (Suppl. 2): S173S179

PopioleK, M., Kotusz, J. (2003): Endoparasitic helmints of fishes of the genus Cobitis from Poland. Folia biol. (Krakow). 51 (Suppl.): 173 - 178

RICKER, W. E. (1975): Computation and interpretation of biological statistics of populations. Bull. Fish. Res. Board Can., 191, 382 pp

RolBIECKI, L. (2004): Distribution of Posthodiplostomum cuticola (Nordmann, 1832) (Digenea; Diplostomidae) metacercariae in Cyprinids of the Vistula lagoon, Poland. Arch. Pol. Fish., 12: 93 - 98

SCHAPERClAUS, W. M. (1990): Fischkrankheiten. Academie Verlag, Berlin. 5. Auflage.

Schuster, R., WANJeK, K., Schein, E. (2001) Investigations on the occurrence of muscle metacercariae in the roach (Rutilus rutilus) from Berlin waters. A contribution to the food hygienic importance of indigenous freshwater fish. Arch. Lebensm. hyg., 52: $102-104$

Shukerova, S. (2005): Helminth fauna of the Prussian carp, Carassius gibelio (Bloch, 1782), from the Srebarna biosphere reserve. Trakia J. Sci., 3: 33 - 40

Shukhgalter, O., Chukalova, N. (2002): An investigation of "black spot" disease of bream (Abramis brama) from Curonian Lagoon, south-east Baltic Sea. Bull. Eur. Assoc. Fish Pathol., 22: 218 - 221

SteEDMAN, R. J. (1991) Occurrence and environmental correlates of black spot disease in stream fishes near Toronto, Ontario. Trans. Am. Fish Soc., 120: 494 - 499 Vuković, T. \& IVAnović, B. (1971): Slatkovodne ribe Jugoslavije. Zemaljski muzej BiH, Sarajevo. 